Entangled Edens 


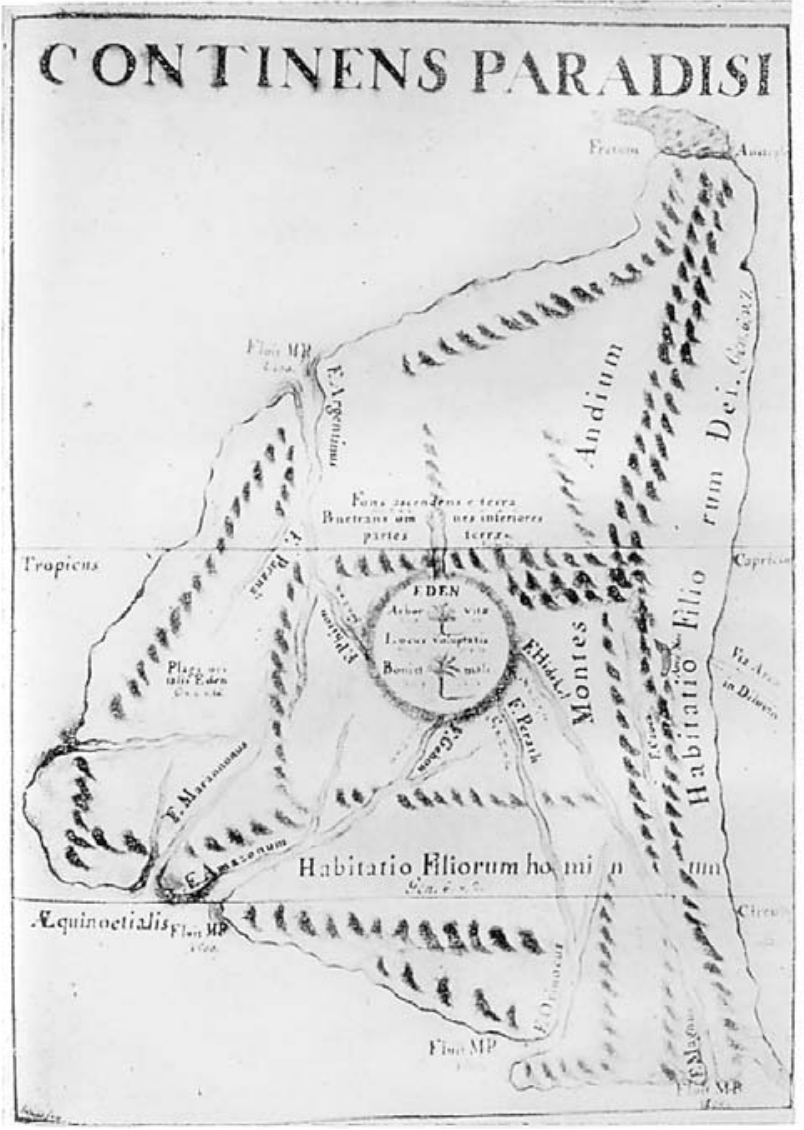

"The Continent of Paradise," a map of South America based on Antonio de León Pinelo's book New World Paradise (El paraíso del Nuevo Mundo). First published in 1656, the map shows Eden at the juncture of the present-day Orinoco, Amazon, and Paraguay Rivers. 


\section{Candace Slater}

\section{Entangled Edens VISIONS OF THE AMAZON}

UNIVERSITY OF CALIFORNIA PRESS

Berkeley / Los Angeles / London 
Excerpt from "Santarém" from the complete POEMS: I927-I 979 by Elizabeth Bishop. Copyright (C) I979, I 983 by Alice Helen Methfessel. Reprinted by permission of Farrar, Straus and Giroux, LLC.

University of California Press

Berkeley and Los Angeles, California

University of California Press, Ltd.

London, England

(C) 2002 by the Regents of the University of

California

Library of Congress Cataloging-in-Publication Data

Slater, Candace

Entangled edens : visions of the Amazon /

Candace Slater.

p. $\mathrm{cm}$.

Includes bibliographical references and index. ISBN 0-520-2264I-O (cloth : alk. paper)

I. Amazon River Region-Description and travel. 2. Utopias-Amazon River Region. 3. Myth. 4. Amazon River Region-Public opinion. I. Title.

F2546.s67 2002

$98 \mathrm{I}-\mathrm{dc} 2 \mathrm{I}$

2001035866

Manufactured in the United States of America $\begin{array}{llllllllll}\text { IO } & 09 & 08 & 07 & 06 & 05 & 04 & 03 & 02 & \text { OI }\end{array}$ $\begin{array}{llllllllll}\text { I0 } & 9 & 8 & 7 & 6 & 5 & 4 & 3 & 2 & \text { I }\end{array}$

The paper used in this publication meets the minimum requirements of ANSI/NISO Z39.48-I992 (R I997) (Permanence of Paper). (-) 
I liked the place; I liked the idea of the place. Two rivers. Hadn't two rivers sprung from the Garden of Eden? No, that was four and they'd diverged. Here only two and coming together. Even if one were tempted to literary interpretations such as: life/death, right/wrong, male / female - such notions would have resolved, dissolved, straight off in that watery, dazzling dialectic.

Here in the Amazon the stories spring up as fast as trees.

Taxi driver, age eighteen, Santarém, Brazil, I995 
This page intentionally left blank 